\title{
ПРЕКРАЩЕНИЕ ОБЯЗАТЕЛЬСТВЕННОГО ПРАВА НА ЗЕМЕЛЬНЫЙ УЧАСТОК ПРИ НАСЛЕДСТВЕННОМ ПРАВОПРЕЕМСТВЕ: ОТДЕЛЬНЫЕ ВОПРОСЫ ПРАВОПРИМЕНЕНИЯ
}

\author{
(c) 2019 Валиуллина Динара Анваровна \\ кандидат юридических наук, доцент \\ Набережночелнинский институт Казанского федерального университета, РТ, Набережные Челны \\ E-mail: MusabirovaDinara@mail.ru \\ (c) 2019 Гизатуллин Ленар Раисович \\ магистрант третьего года обучения \\ Набережночелнинский институт Казанского федерального университета, РТ, Набережные Челны
}

Статья направлена на освещение некоторых особенностей порядка приобретения обязательственного права на особый объект, передаваемый в порядке универсального правопреемства,право аренды земельного участка. Отмечаются сложности в трактовании права аренды как тесно связанного с личностью, что влечет за собой прекращение указанной договорной связи, а не изменение её в порядке наследования. На основе анализа судебной практики делается вывод об особенностях трактования категории «личные качества» наследодателя при предоставлении участка в аренду.

Ключевые слова: аренда земельного участка, наследование, прекращение обязательства.

Общепринято, что земля является вещью особого рода, к которой применяются специфические правила правового регламентирования. Выделение такого объекта из всего массива объектов гражданского права легко аргументировать особым социальным значением природных ресурсов, а также принципом дуплицета недвижимости, являющегося сутью современной отечественной парадигмы системы недвижимых вещей. Именно с землей, как правило, связаны и иные объекты, также являющиеся недвижимостью, а именно - здания, строения и т.д., имеющие значительную стоимость и общественное значение.

Введение земельных участков в оборот зачастую опосредуется заключением договоров аренды. Обычно указанные договорные связи не подвержены изменению субъектного состава, но в отдельных случаях определенная трансформация неизбежна, классический пример - универсальное правопреемство в порядке наследования.

Имущество умершего при наследовании, как известно, переходит к другим лицам (п. 1 ст. 1110 Гражданского кодекса РФ (далее - ГК РФ). При этом в состав наследства входят принадлежавшие наследодателю на день открытия наследства вещи, иное имущество, в том числе имущественные права и обязанности и не вклю- чаются личные неимущественные права и иные материальные блага, права и обязанности, неразрывно связанные с личностью наследодателя (в частности, право на алименты, право на возмещение вреда, причиненного жизни или здоровью гражданина), а также права и обязанности, переход которых в порядке наследования не допускается ГК РФ или другими законами.

Основной акт цивилистического законодательства в отношении договора аренды, в том числе и земельных участков, предусматривает отдельное нормативное указание по поводу правопреемства. Ст. 617 ГК РФ указывает, что в случае смерти гражданина, арендующего недвижимое имущество, его права и обязанности по договору аренды переходят к наследнику, если законом или договором не предусмотрено иное. Это правило, правда, имеет одну, на первый взгляд, весьма несущественную оговорку: арендодатель вправе отказать наследнику в случае, если заключение договора обусловлено личными качествами арендатора.

На первый взгляд положения ГК РФ об арендного рода обязательствах вторят общим положениям о наследовании. В то же время, как показывает анализ правоприменительной практики, если обязательства, исключаемые из круга наследуемого имущества, редко становятся предметом судебных препирательств, то катего- 
рия «личные качества арендатора» имеет весьма неоднозначную трактовку.

Согласимся с Н. Костылевой и В.М. Костылевым, что причиной тому является прием законодательной техники, использованный при конструировании рассматриваемых норм,упоминание родовой категории и примеров таковой, который «... едва ли можно считать удачным, так как тем самым дезориентируются не только субъекты законодательства (граждане), но и те, кто обязан толковать закон (юристы)» [6; C. 39]. Действительно, установленное законодательством нормативное регламентирование на данный момент порождает значительное количество правовых проблем при рассмотрении вопросов правопреемства.

Справедливо будет отметить, что в большинстве случаев (когда стороны не вступают в «баталии» по существу) суды, не вдаваясь в тонкости дела, лишь формально применяют правило п. 2 ст. 617 ГК РФ, указывая следующее: «... из содержания договора аренды земельного участка не следует его заключение не обусловлено личными качествами арендатора» [2; 10]. Таким образом, вопрос о личном характере обязательственного права аренды судами просто не исследуется. Однако существует значительный массив дел, в которых наличие у наследодателя статуса индивидуального предпринимателя или председателя крестьянско-фермерского хозяйства (далее - КФХ) становится серьезным камнем преткновения при определении судьбы обязательственного правоотношения.

Оформленные официально позиции правоприменителя по этому вопросу могут быть разделены на две основные группы. В решениях первого порядка [3; 13] суды исходят из постулата о неразрывности с личностью статуса индивидуального предпринимателя, каковой в силу ст. 23 ГК РФ и Федерального закона от 8 августа 2001 г. № 129-Ф3 «О государственной регистрации юридических лиц и индивидуальных предпринимателей» [15] прекращается со смертью гражданина. Более подробно в существующих актах судебной практики исследуется вопрос о значении статуса КФХ для заключенного наследодателем соглашения. Здесь, помимо личного характера реализации предпринимательской деятельности, суды прибегают к доводам об особой цели передачи земельного участка. Обычно это сельскохозяйственные земли, потому и цель их передачи может быть осуществлена только самим председателем КФХ, а не его наследниками [12].

Вторая позиция абсолютно диаметральна первой и приводит к признанию факта правопреемства в рамках арендного правоотношения с участием предпринимателя-наследодателя. Иллюстративно в этом плане Апелляционное определение Верховного суда Республики Татарстан от 18 января 2016 г. по делу № 33-860/2016: «В этой связи, судебная коллегия находит не основанным на законе вывод суда первой инстанции о том, что имущественные права 3. по договору аренды земли № 2009 от 3 декабря 2001 года прекращены с ее смертью, поскольку личный характер обязательства в данном случае должен определяться с учетом конкретных обстоятельств, которых, по мнению судебной коллегии, по материалам дела не имеется» [1]. Как видим, наличие статуса предпринимателя прямо констатируется в качестве не связанного с личностью.

Отметим наличие и третьей - фактически промежуточной - позиции правоприменителя о распространении правила о значимости статуса предпринимателя лишь в отношении пользования землями публичной формы собственности. Она была отражена, в частности, в тексте Решения Богучарского районного суда Воронежской области № 2-211/2016 от 16 марта 2016 г. по делу № 2-211/2016 [9]. Истоки такой позиции содержатся в подзаконном акте рекомендательного характера - Письме ФАС России от 12 декабря 2013 г. № АД/50427/13 «Об оказании методической помощи» [8]. Однако широкого применения этот акт не получил.

Примечательно, что первая и вторая позиции аргументируется одними и теми же правовыми предписаниями (ст. 23, 418, 617, 1112 ГК РФ), но выносимые правоприменителями резюме отличаются кардинально.

Вся «соль» такого разнообразия судебных позиций заключается в различном трактовании ключевого понятия «личные качества» арендатора. Безусловно, что термин «личность» и всего его производные не являются нормативными категориями. Обычно это дефиниции используются психологией, социологией, философией. Так, философия под личностью понимает: «1) устойчивую систему социально значимых черт, характеризующих индивида как члена того или иного общества или общности; 2) индивидуального носителя этих черт как свободного и 
ответственного субъекта сознательной волевой деятельности» [16; С. 313]. Понятие же личности в психологии является первостепенным и означает наиболее развитый уровень человеческой субъективности, т.е. совокупность привычек, наклонностей, психических и культурных настроек, социокультурного опыта, уровня знаний, психофизических особенностей, определяющих поведение индивида в обществе [4; С. 107].

K сожалению, в доктрине права вопросам определения личных качеств в рассматриваемом нами контексте также не уделено должного внимания. Отметим лишь диссертационное исследование Е.И. Ворониной, которая верно подмечает, что понятие «субъект права» (в том числе и как сторона обязательственного правоотношения) предполагает абстрагирование от свойств конкретного лица, в то время как «личность» характеризуется именно включением в себя черт, характеризующих и максимально индивидуализирующих данное лицо [5; С. 5].

Определенным образом созвучно такой теоретической позиции и реноме правоприменителя: «Таким образом, в договоре указано лишь на то, что ФИОЗ является индивидуальным предпринимателем, что характеризует не его личные качества, а правовой статус стороны договора» [11].

Разумны и доводы по другому судебному делу [14]. Истцы полагали, что личность арендатора для них имеет существенное значение, т.к. наследодатель знал все тонкости сельхоз работ, участвовал в деятельности КФХ производя лично различные работы, т.е. он имел необходимые навыки для указанной деятельности. Однако, суд резюмировал, что выращивание сельхозкультур, не может быть отнесено к виду деятельности, при котором личностные качества лица имеют существенное значение, поскольку лица, занимающиеся работами в данной сфере, обладают необходимыми навыками либо сами, либо посредством найма необходимых специалистов.

Отметим, что в данном судебном акте дается еще один ориентир определения значимости личности для конкретного обязательства. Как справедливо указал суд, договор аренды содержал условие о возможности передачи земельного участка в субаренду. Следовательно, любое третье лицо могло стать стороной обязательства, что говорит о не персонифицированном характере заключенной сделки.

В заключение хотелось бы отметить, что сложившаяся ситуация приводит к существенному ущемлению прав граждан и дисгармонизирует цивилистический оборот. Полагаем, второй подход, выработанный судебной практикой, наиболее согласуется с духом и буквой действующего законодательства и способствует стабильности гражданского оборота. Наличие статуса предпринимателя не связано с характеристиками субъекта права именно как личности, ведь к претендентам при регистрации не предъявляется никаких личных требований. Более того, правила о регистрации максимально формализованы.

В то же время, учитывая, что заключение договора с учетом личных качеств контрагента, как было верно отмечено Конституционным Судом РФ, является отражением принципа свободы договора [7], логично, что именно в договоре аренды земельного участка должно получать отражение указание на личный характер возникающего обязательства. Именно в таком случае возможно применение правила о прекращении обязательственного права по смыслу ст. 617 ГК РФ.

\section{Библиографический список}

1. Апелляционное определение Верховного суда Республики Татарстан от 18 января 2016 г. по делу № 33860/2016 // СПС «КонсультантПлюс».

2. Апелляционное определение Ленинградского областного суда от 26 апреля 2018 г. по делу № 33-1760/2018 // СПС «КонсультантПлюс».

3. Апелляционное определение Судебной коллегии по гражданским делам Краснодарского краевого суда № 33-8791/2014 от 6 мая 2014 г. по делу № 33-8791/2014 // СПС «КонсультантПлюс».

4. Асмолов А.Г. Психология личности. М.: МГУ, 1990.367 с.

5. Воронина Е.И. Гражданско-правовые обязательства, связанные с личностью их сторон: автореф. дисс. ... к.ю.н. М., 2014. 26 с.

6. Костылева Н., Костылев В.М. К вопросу об определении понятия наследства // Бюллетень нотариальной практики. 2008. № 2. С. 38-42.

7. Определение Конституционного Суда РФ от 20 ноября 2003 г. № 438-О // СПС «КонсультантПлюс». 
8. Письмо ФАС России от 12 декабря 2013 г. № АД/50427/13 «Об оказании методической помощи» // СПС «КонсультантПлюс».

9. Решение Богучарского районного суда Воронежской области № 2-211/2016 от 16 марта 2016 г. по делу № 2-211/2016 // СПС «КонсультантПлюс».

10. Решение Котласского городского суда Архангельской области от 22 апреля 2019 г. по делу № 2-632/2019 М-365/2019 // СПС «КонсультантПлюс».

11. Решение Куртамышского районного суда Курганской области № 2-473/2017 от 20 июля 2017 г. по делу № 2-473/2017 // СПС «КонсультантПлюс».

12. Решение Оренбургского районного суда Оренбургской области № 2-2818/2016 от 14 сентября 2016 г. по делу № 2-2818/2016 // СПС «КонсультантПлюс».

13. Решение Павловского районного суда Воронежской области № 2-В281/2014 от 30 сентября 2014 г. // СПС «КонсультантПлюс».

14. Решение Староминского районного суда Краснодарского края № 2-20/2018 от 18 мая 2018 г. по делу № 2-20/2018 // СПС «КонсультантПлюс».

15. Федеральный закон от 8 августа 2001 г. № 129-Ф3 «О государственной регистрации юридических лиц и индивидуальных предпринимателей» // Собрание законодательства РФ. 2001. № 33. Ст. 3431.

16. Философский энциклопедический словарь. М., 1989. 814 с. 